Bài báo khoa hoc

\title{
Nghiên cứu đề xuất khung quản lý tổng hợp an toàn hồ đập tại Việt Nam
}

\author{
Nguyễn Cao Đơn ${ }^{1}$, Nguyễn Thị Minh Hằng ${ }^{2} *$, Nguyễn Anh Đức ${ }^{3}$ \\ ${ }^{1}$ Phòng Quy hoạch và Dự báo tài nguyên nước, Viện Khoa học tài nguyên nước (Bộ Tài \\ nguyên và Môi trường), Số 8 Phố Pháo Đài Láng, Đống Đa, Hà Nội; \\ ncaodonwru@gmail.com \\ ${ }^{2}$ Trường Đại học Thủy lợi, số 175 Phố Tây Sơn, Đống Đa, Hà Nội; hangntm @tlu.edu.vn \\ ${ }^{3}$ Viện Khoa học tài nguyên nước, Số 8 Phố Pháo Đài Láng, Đống Đa, Hà Nội; \\ nganhduc@yahoo.com \\ * Tác giả liên hệ: hangntm @tlu.edu.vn; Tel.: +84-354607643
}

Ban Biên tập nhận bài: 12/8/2020; Ngày phản biện xong: 27/9/2020; Ngày đăng bài: 25/10/2020

Tóm tắt: Việt Nam là đất nước có rất nhiều hồ chứa nước trong đó có tới gần $90 \%$ là đập đất. Hiện nay đã có nhiều hồ đập có nguy cơ mất an toàn do đa phần được xây dựng trong những năm chiến tranh với kỹ thuật khảo sát và thiết kế hạn chế, thiết bị thi công không đáp ứng yêu cầu kỹ thuật, thiếu hoặc không có khung pháp lý an toàn đập, thiếu hoặc không có quy trình vận hành và không được sửa chữa định kỳ, thiếu năng lực dự báo và bị xuống cấp. Nghiên cứu này đã đề xuất khung pháp lý phục vụ quản lý an toàn hồ đập ở Việt Nam, bao gồm các hoạt động tăng cường thể chế chính sách và pháp luật và một loạt các hành động nhằm ứng phó với rủi ro an toàn đập, xây dựng chiến lược quản lý rủi ro thiên tai và hệ thống sẵn sàng ứng phó khẩn cấp, thực hiện các kế hoạch hành động cho khả năng chống chịu của khu vực và quốc gia.

Từ khóa: Khung pháp lý; An toàn hồ đập; Hành động khẩn cấp; Hồ chứa nước; Quản lý an toàn.

\section{Mở đầu}

Việt Nam là một quốc gia có nền kinh tế dựa vào nông nghiệp và là một trong những quốc gia dễ tổn thương nhất với thiên tai có nguồn gốc khí tượng thủy văn do tính chất địa hình, địa lý, cơ cấu kinh tế và phân bổ dân cư. Nguồn tài nguyên nước phong phú với 14 lưu vực sông chính trên khắp cả nước, nhưng lại được phân bố không đồng đều trong không gian và theo thời gian. Ngành nông nghiệp đã phụ thuộc rất nhiều vào công tác tưới, tiêu và kiểm soát lũ. Thiên tai là một thách thức đối với sự phát triển của Việt Nam. Trong khi lũ và bão là mối nguy hiểm chính thì Việt Nam cũng dễ bị tổn thương bởi hạn hán, sạt lở và xâm nhập mặn [1]. Việt Nam cũng đang chịu nhiều tác động của biến đổi khí hậu [2-6]. Do đầu tư vào phát triển tài nguyên nước, Việt Nam đã có một mạng lưới hồ đập và cơ sở hạ tầng thủy lợi lớn với hơn 7000 đập các loại (kể cả đập thủy điện). Trong đó có hơn 750 đập được xếp loại là đập lớn (có chiều cao hơn $15 \mathrm{~m}$ hoặc từ $5-15 \mathrm{~m}$ với dung tích hồ chứa hơn 3 triệu $\mathrm{m}^{3}$ ) và hơn 6.000 đập nhỏ (có chiều cao dưới $15 \mathrm{~m}$ và dung tích đập dưới 3 triệu $\mathrm{m}^{3}$ ) mà phần lớn là đập đất. Trong tổng số 4 triệu hecta đất nông nghiệp thì có hơn 3 triệu hecta được tưới thông qua 6.648 đập thủy lợi [5]. Ngoài ra, còn có hơn 429 hồ thủy điện lớn với tổng dung tích khoảng 56 tỷ $\mathrm{m}^{3}$ chiếm $86 \%$ tổng dung tích hồ chứa trên địa bàn cả nước [6]. 
Việc phát triển cơ sở hạ tầng này đã tạo ra một số thách thức. Nhiều hồ chứa quy mô vừa và nhỏ được xây dựng từ những năm 1960-1980 với kỹ thuật khảo sát thiết kế hạn chế, công nghệ thi công chưa đảm bảo chất lượng, năng lực quản lý, vận hành hạn chế và chậm bảo trì. Kết quả là, nhiều đập đã bị xuống cấp và mức độ an toàn của đập thấp hơn so với tiêu chuẩn quốc tế, làm gia tăng rủi ro đáng kể đối với con người và an ninh kinh tế. Sự xuống cấp của các hồ đập này càng tăng lên do tác động của các hiện tượng thời tiết cực đoan, lũ lụt và biến đổi khí hậu. Sự phát triển thượng nguồn nhanh chóng cũng đã khiến nhiều hồ chứa trong tình trạng rủi ro. Các dạng rủi ro hư hỏng đập bao gồm cố kết và lún của kết cấu chính, thấm qua đập chính, đập phụ và xung quanh công trình lấy nước, biến dạng của mái thương/hạ lưu, đập tràn không đủ năng lực tháo lũ, thiếu thiết bị giám sát an toàn [5].

Để hồ chứa phát huy được năng lực theo thiết kế, đảm bảo an toàn tính mạng và tài sản cho vùng hạ du thì an toàn của đập trở nên rất quan trọng và có tính quyết định đến hiệu quả hoạt động của hồ chứa. An toàn hồ đập liên quan đến an toàn kết cấu công trình, giám sát vận hành, bảo trì và cảnh báo sớm để xây dựng các kế hoạch chuẩn bị và ứng phó với các tình huống khẩn cấp. Ngành Nông nghiệp và Phát triển nông thôn có hơn 6648 đập, trong đó nếu tính theo phân loại đập theo vật liệu xây dựng đập thì có tới gần $90 \%$ là đập đất với những đặc điểm: (i) Hồ đập đa phần được xây dựng đã lâu, từ những năm 1960-1980 với kỹ thuật khảo sát hạn chế, thiếu các tiêu chuẩn, quy phạm thiết kế, thiết bị thi công không đáp ứng yêu cầu kĩ thuật, thiếu hoặc không có khung pháp lý an toàn đập, thiếu hoặc không có quy trình vận hành và không được sửa chữa định kỳ, thiếu năng lực dự báo từ đó bị xuống cấp; (ii) Đập đất được thi công thủ công là chính nên dễ bị sự cố; (iii) Quản lý hồ đập mới chú trọng khai thác sử dụng, ít quan tâm đến nghiên cứu trên công trình thực tế; (iv) Biến đổi khí hậu, tạo ra những hình thái thời tiết cực đoan, làm nguy cơ mất an toàn đập ngày càng cao; (v) Sự phát triển kinh tế xã hội vùng hạ du đòi hỏi an toàn đập ở mức độ cao hơn.

Về tổ chức quản lý hồ đập, đến nay, vẫn còn tồn tại một số điểm trong khung pháp lý và thể chế quản lý an toàn hồ đập ở Việt Nam. Rất nhiều hồ chứa chưa có quy trình vận hành điều tiết, cũng chưa có kế hoạch ứng phó trong các tình huống khẩn cấp và ứng cứu đập (ngoại trừ một số hồ đập thuộc Dự án WB8 [5]). Các công trình phục vụ quản lý như đường xá chưa đảm bảo cho xe cơ giới tiếp cận để kiểm tra, ứng cứu khi công trình có sự cố, thậm chí một số hồ không có đường quản lý theo qui định. Các phương tiện thông tin, liên lạc, thiết bị quan trắc chưa được trang bị đầy đủ, dân đến khó khăn trong chỉ huy điều hành nhất là trong mùa mưa lũ. Phần lớn các hồ chứa là do các xã, hợp tác xã quản lý, các doanh nghiệp nhà nước (công ty quản lý thuỷ nông) quản lý và đã dẫn đến nhiều hư hỏng, đe doạ đến an toàn, tuy nhà nước đã và đang tập trung đầu tư sửa chữa tốn kém, nhưng an toàn hồ đập vẫn là mối lo ngại do nguồn tài chính đầu tư cho việc sửa chữa, nhất là đầu tư cho quản lý chưa đáp ứng được yêu cầu kỹ thuật, bền vững. Hầu hết các đập loại vừa và nhất là đập nhỏ, đều do dân (ủy ban nhân dân xã, hợp tác xã) quản lý, nhiều trường hợp đập đã có "chủ quản lý”, nhưng lại không có người quản lý thường xuyên, có nghĩa là không có "chủ đích thực", vấn đề này cũng đe doạ đến an toàn của hồ đập [7].

\section{Phương pháp nghiên cứu}

Thông qua việc nghiên cứu một số văn bản pháp lý liên quan đến quản lý an toàn hồ đập trên thế giới và tại Việt Nam cho thấy vấn đề quản lý an toàn đập đã được Chính phủ các nước và Việt Nam rất quan tâm. Riêng tại Việt Nam, Chính phủ và các bộ ngành đã ban hành nhiều văn bản quy định việc quản lý an toàn đập và được hoàn thiện dần cho đến hiện tại. Các văn bản pháp lý được nghiên cứu phân tích bao gồm: (i) Các luật của nước Cộng hòa Xã hội Chủ nghĩa Việt Nam; (ii) Pháp lệnh về khai thác và bảo vệ công trình thủy lợi; (iii) Các nghị định, quyết định của Chính phủ; (iv) Các thông tư, tiêu chuẩn quốc gia, tiêu chuẩn kỹ thuật của các bộ ngành.

Nghiên cứu này đi sâu phân tích vai trò và trách nhiệm của các cơ quan khác nhau được quy định, vai trò và trách nhiệm của các bộ ngành liên quan, và một số điểm còn tồn tại trong 
thể chế quản lý an toàn hồ đập ở Việt Nam, từ đó đề xuất được khung pháp lý quản lý tổng hợp an toàn hồ đập tại Việt Nam.

\section{Kết quả và thảo luận}

\subsection{Chính sách, pháp lý quản lý lũ lụt và an toàn hồ đập tại một số nước}

Hoa Kỳ, Nhật Bản và Hàn Quốc là ba trong số các nước trên thế giới có mạng lưới hồ đập và cơ sở hạ tầng thủy lợi lớn trên thế giới. Tại Hoa Kỳ đã có Khung kế hoạch hành động khẩn cấp của Cơ quan quản lý trường hợp khẩn cấp liên bang (FEMA) và Bộ An ninh nội địa Hoa Kỳ (Department of Homeland Security, DHS), và đã thành lập các kế hoạch khẩn cấp phục vụ công tác phòng chống, ứng phó khẩn cấp với các thảm họa tự nhiên. FEMA và DHS đã xây dựng khung kế hoạch hành động khẩn cấp rõ ràng đối với hồ đập. Mục tiêu chính của hướng dẫn liên bang về an toàn đập-kế hoạch hành động khẩn cấp đối với các đập của FEMA là bảo vệ tính mạng con người và giảm thiểu thiệt hại tài sản trong các thảm họa tự nhiên hoặc tình huống khẩn cấp. Mục tiêu chính của hướng dần chuẩn bị khẩn cấp cho đê điều của DHS là tổ chức ứng phó phối hợp hiệu quả với lũ lụt bằng cách phân định các nhiệm vụ chính để lập kế hoạch, tổ chức, đào tạo, chuẩn bị thiết bị, thực hiện và đánh giá. Trong hướng dẫn kế hoạch hành động khẩn cấp cho đập của FEMA nhấn mạnh sáu yếu tố của kế hoạch hành động khẩn cấp gồm: sơ đồ thông báo và thông tin liên hệ, quy trình phản ứng, trách nhiệm, hoạt động chuẩn bị, bản đồ ngập lụt và thông tin bổ sung trong các phụ lục. Quá trình phản ứng trong kế hoạch hành động khẩn cấp bao gồm bốn bước: (i) Phát hiện, đánh giá sự cố và xác định mức độ khẩn cấp; (ii) Thông báo và liên lạc; (iii) Hành động khẩn cấp; và (iv) Chấm dứt và theo dõi.

Tại Nhật Bản, Bộ Đất đai, cơ sở hạ tầng, giao thông và du lịch [8] đã công bố hướng dẫn xây dựng kế hoạch phòng chống lũ lụt dựa trên Điều 7 khoản 1 của Luật Cơ bản về phòng chống thiên tai. Hướng dẫn này nêu chi tiết tất cả các bước cần thiết để phối hợp trách nhiệm và thực hiện các biện pháp kiểm soát lũ trong trường hợp xảy ra thảm họa lũ lụt trong một khu vực. Mục tiêu được đặt ra là duy trì cảnh giác và bảo vệ chống lũ lụt, sóng thần và thủy triều dâng cao, để giảm thiểu thiệt hại và đảm bảo an toàn cho cộng đồng. Hướng dẫn kiểm soát lũ lụt được đề cập ở trên bao gồm kế hoạch hành động khẩn cấp cho lũ sông, hướng dẫn chỉ định các vùng dễ bị lũ lụt và cung cấp các kế hoạch sơ tán để ứng cứu người. Kế hoạch sơ tán và kế hoạch phòng chống lũ lụt được biên soạn liên quan đến khu vực dễ bị lũ lụt, các cơ sở được sử dụng bởi người dân, các nhà máy lớn và kế hoạch này được phản ánh trong thiết kế của tòa nhà. Các công trình được sử dụng bởi các nhóm dễ bị tổn thương hơn như người già, người khuyết tật và trẻ sơ sinh được chỉ định là khu vực dễ bị lũ lụt để cho phép các biện pháp sơ tán nhanh chóng. Hướng dẫn xây dựng kế hoạch phòng chống lũ liệt kê các giai đoạn ứng phó khẩn cấp gồm Giai đoạn 1 (Chờ), Giai đoạn 2 (Chuẩn bị), Giai đoạn 3 (Huy động), Giai đoạn 4 (Cảnh giác) và Giai đoạn 5 (Giảm dần mức báo động).

Tại Hàn Quốc, tất cả các hệ thống quản lý rủi ro của các cơ quan liên quan đều tuân theo tư vấn về rủi ro được mã hóa theo thang màu của Bộ Nội vụ và An ninh Hàn Quốc [9]. Thang đo rủi ro bao gồm bốn màu: xanh lam (được bảo vệ), vàng (rủi ro trung bình), cam (rủi ro cao) và đỏ (rủi ro nghiêm trọng).

Trước đây, khái niệm "kiểm soát lũ" (Flood control) thường được dùng để hạn chế những rủi ro do lũ gây ra, tuy nhiên, những nghiên cứu về lũ trên thế giới trong thời gian gần đây cho thấy khái niệm "quản lý lũ̃" (Flood management) đã được dùng để thay thế khái niệm "kiểm soát lũ". Quản lý lũ mang tính tổng quát hơn kiểm soát lũ vì nó đòi hỏi cách tiếp cận đa chiều, đa tầng và đa lĩnh vực, trong đó, sự tham gia, chia sẻ kiến thức của tất cả các nhóm xã hội, lồng ghép kế hoạch phát triển các ngành kinh tế với kế hoạch phòng chống lũ là việc mà toàn xã hội phải thực hiện. Để thực hiện thành công cách tiếp cận tổng hợp nói trên, các nhà khoa học trên thế giới đã đưa ra nhiều khung hành động (framework), chỉ dẫn (guideline), hướng dẫn (handbook)... Tuy có khác nhau về cách cầu trúc ý tưởng nhưng nhìn 
chung, việc quản lý lũ phải được thực hiện theo chu trình khép kín, lặp đi lặp lại các bước thực hiện ngắn hạn, trung hạn và dài hạn tùy theo bản chất của từng nội dung hành động.

Hướng dẫn xây dựng kế hoạch hành động khẩn cấp ở các quốc gia trên thế giới được tóm tắt thành bốn giai đoạn bao gồm Giảm thiểu, Chuẩn bị, Phản ứng và Phục hồi. Trong đó, các nước Hàn Quốc và Nhật Bản nhấn mạnh tầm quan trọng trong giai đoạn Phản ứng và Phục hồi, trong khi đó giai đoạn Giảm thiểu và Chuẩn bị lại được Hoa Kỳ quan tâm hơn.

Đối với Hoa Kỳ, Hướng dẫn khung kế hoạch hành động khẩn cấp bao gồm các chi tiết đủ điều kiện để 'Giảm thiểu' và chủ yếu đề xuất các vấn đề cần chuẩn bị trong những ngày bình thường như thành phần tổ chức để ứng phó với tình huống khẩn cấp, chuẩn bị tài nguyên, vận hành cơ sở, phát hiện sự cố và xây dựng của hệ thống đánh giá rủi ro.

Các hoạt động nhằm "Giảm thiểu", "Chuẩn bị", "Phản ứng/Úng phó" và "Phục hồi” rủi ro thiên tai, lũ lụt, bảo đảm an toàn hồ đập chứa nước kể trên đã được các tác giả chọn lọc, có chỉnh sửa và cập nhật theo điều kiện Việt Nam để xây dựng khung pháp lý quản lý tổng hợp an toàn hồ đập tại Việt Nam.

\subsection{Các văn bản pháp luật và chính sách quản lý an toàn hồ đập ở Việt Nam}

Tại Việt Nam, Chính phủ và các bộ ngành đã ban hành nhiều văn bản quy định việc quản lý an toàn đập và được hoàn thiện dần cho đến hiện tại. Hiện nay đã có 05 văn bản luật điều chỉnh các nội dung này gồm Luật tài nguyên nước [10], Luật Phòng, chống thiên tai [11], Luật Thủy lợi [12], Luật Đê điều [13], và Luật Sửa đổi, bổ sung một số điều của Luật phòng, chống thiên tai và Luật đê điều [14]. Ngoài ra, Luật Khí tượng thủy văn (KTTV) đã tạo hành lang pháp lý cho các hoạt động chuyên môn KTTV phát triển, đáp ứng yêu cầu của công tác phòng, chống thiên tai, ứng phó với biến đổi khí hậu.

Dưới luật còn có các nghị định như Nghị định 114/2018/NĐ-CP về Quản lý an toàn đập, hồ chứa nước [15] (thay thể Nghị định 72/2007/NĐ-CP về Quản lý an toàn đập) áp dụng quy tắc quốc tế trong việc định nghĩa các đập dựa trên chiều cao và dung tích. Đặc biệt, Nghị định định rõ phân loại đập, hồ chứa nước. Nghị định số 67/2018/NĐ-CP [16] ngày 14 tháng 5 năm 2018 của Chính phủ quy định chi tiết một số điều của Luật Thủy lợi. Việc phân loại đập, hồ chứa nước được thực hiện theo quy định tại Điều 3 Nghị định này. Nghị định số 160/2018/NĐ-CP [17] của Chính phủ Quy định chi tiết thi hành một số điều của Luật phòng, chống thiên tai.

Vai trò và trách nhiệm của các cơ quan khác nhau được quy định trong một loạt các Thông tư sau đó của Chính phủ. Các thông tư này được xây dựng và có hiệu lực để trực tiếp quản lý an toàn đập/hồ chứa. Thông tư 33/2008/TT-BNN [18] nêu chi tiết vai trò của Bộ Nông nghiệp và Phát triển nông thôn (NN\&PTNN) đối với các hồ đập thủy lợi và Thông tư 34/2010/TT-BTC [19] quy định chi tiết vai trò của Bộ Công thương liên quan đến đập thủy điện. Bộ Tài nguyên và Môi trường (TN\&MT) chịu trách nhiệm xây dựng các kế hoạch điều tiết nước liên hồ chứa và quy tắc vận hành ở 11 lưu vực sông nơi có chuỗi đập/hồ chứa bậc thang tại Nghị định 21/2013/NĐ-CP [20].

Vai trò và trách nhiệm của Bộ TN\&MT, Bộ NN\&PTNT và Bộ Công thương liên quan đến quản lý tổng hợp các hồ chứa thủy điện và thủy lợi được nêu chi tiết trong Nghị định 112/2008/NĐ-CP [21]. Nghị định này bao gồm các quy định về kế hoạch điều tiết nước liên hồ chứa bao gồm cả hạn hán nghiêm trọng, ô nhiễm nước, các sự cố về môi trường hay thiên tai. Các nghị định và thông tư cũng quy định rõ vai trò và trách nhiệm của các tổ chức cấp tỉnh và cấp huyện và các đơn vị liên quan khác. Những điểm cần lưu ý trong nghị định: Tài nguyên và môi trường các hồ chứa phải được khai thác, sử dụng tổng hợp, tiết kiệm, hiệu quả, không chia cắt theo địa giới hành chính. Bảo vệ tài nguyên và môi trường các hồ chứa phải trên cơ sở tăng cường quản lý nhà nước, thể chế, pháp luật và tuyên truyền, giáo dục, nâng cao ý thức trách nhiệm của người dân, cộng đồng dân cư vùng hồ chứa.

Việc khai thác, sử dụng tài nguyên và môi trường các hồ chứa phải bảo đảm an toàn hồ chứa, dòng chảy tối thiểu, không ảnh hưởng đến các mục tiêu, nhiệm vụ của hồ chứa đã được 
các cơ quan có thẩm quyền phê duyệt và đáp ứng các yêu cầu về phòng, chống suy thoái, cạn kiệt, ô nhiễm nguồn nước và phòng, chống tác hại do nước gây ra trên lưu vực hồ chứa và hạ du hồ chứa. Phải lập hành lang bảo vệ hồ chứa, cắm mốc giới xác định hành lang bảo vệ hồ chứa trình Ửy ban nhân dân cấp tỉnh nơi có hồ chứa phê duyệt. Phải xây dựng quy trình điều tiết nước hồ chứa. Quy trình vận hành hồ chứa phải được lập đáp ứng đầy đủ các nhiệm vụ của hồ chứa theo thứ tự ưu tiên, bảo đảm an toàn công trình, an toàn hạ du hồ chứa, khai thác tổng hợp tài nguyên, môi trường hồ chứa, duy trì dòng chảy tối thiểu ở hạ lưu hồ chứa, không gây biến đổi lớn đến chế độ dòng chảy hạ lưu hồ và có tính đến yếu tố biến đổi khí hậu [21].

Nghị định 43/2015/NĐ-CP [22] quy định việc lập, quản lý hành lang bảo vệ nguồn nước. Đối với hồ chứa thủy điện, thủy lợi có dung tích lớn hơn một tỷ mét khối hoặc có dung tích từ mười triệu mét khối đến một tỷ mét khối nhưng nằm ở địa bàn dân cư tập trung, địa bàn có công trình quốc phòng, an ninh thì phạm vi hành lang bảo vệ nguồn nước là vùng tính từ đường biên có cao trình bằng mực nước cao nhất ứng với lũ thiết kế đến đường biên có cao trình bằng cao trình giải phóng mặt bằng lòng hồ. Đối với các loại hồ chứa thủy điện, thủy lợi khác, phạm vi hành lang bảo vệ nguồn nước là vùng tính từ đường biên có cao trình bằng cao trình đỉnh đập đến đường biên có cao trình bằng cao trình giải phóng mặt bằng lòng hồ [22].

\subsection{Một số điểm còn tồn tại trong thể chế quản lý an toàn hồ đập ở Việt Nam}

Luật Tài nguyên nước quy định về quản lý, bảo vệ, khai thác, sử dụng tài nguyên nước, phòng, chống và khắc phục hậu quả tác hại do nước, trong đó các nội dung có đề cập đến phòng chống tác hại của nước, quy định về khai thác, vận hành hồ chứa, các quy định về phòng chống lũ thì không quy định cụ thể mà dẫn chiếu tới các quy định hiện hành về đê điều và phòng chống lũ; việc bảo vệ lòng, bờ, bãi sông; chỉ đạo việc thực hiện các biện pháp bảo vệ lòng, bờ, bãi sông đối với các sông là ranh giới giữa hai tỉnh, thành phố trực thuộc trung ương.

Tại Điều 5 Nghị định số 201/2013/NĐ-CP [23] quy định chi tiết thi hành một số điều của Luật Tài nguyên nước “quy định về Tổ chức lưu vực sông”. Tuy nhiên, đến nay tại một số khu vực vẫn chưa có tổ chức nào quản lý lưu vực sông liên tỉnh được thành lập.

Hiện nay, một hồ chứa có khi chịu cả sự quản lý của 3 bộ ngành, gồm có Bộ Công thương, Bộ Tài Nguyên và Môi trường (TNMT) và Bộ Nông nghiệp và Phát triển Nông thôn (NNPTNT). Bộ TNMT quản lý nước như một tài nguyên và là tài sản công, thuộc sở hữu toàn dân. Bộ Công thương quản lý việc xây dựng các công trình thủy điện, sản xuất điện và xem xét điện là một sản phẩm hàng hóa. Trong khi đó, Bộ NNPTNT thì quản lý việc cấp nước. Do vậy, trong thực tế, vẫn còn có khó khăn trong vận hành một số hồ chứa thủy điện [6]. Vào mùa kiệt, trong một số trường hợp, yêu cầu về điều tiết nước các hồ chứa trong mùa kiệt còn chồng chéo giữa Bộ NNPTNT với Bộ TNMT. Do đó, việc lập kế hoạch vận hành của các hồ chứa thủy điện vừa đáp ứng nhu cầu phụ tải điện vừa đáp ứng nhu cầu sử dụng nước còn có khó khăn. Vào mùa lũ, việc quy định thời gian tích nước cuối mùa lũ khá ngắn và việc vận hành tích nước phụ thuộc rất nhiều vào chất lượng của các bản tin dự báo thời tiết làm cho việc tích nước các hồ chứa thủy điện gặp khó khăn. Đặc biệt là trong những năm ít lũ, lưu lượng nước về thấp thì các hồ không tích được đến mực nước dâng bình thường để đảm bảo cho công tác phát điện và trữ nước phục vụ nhu cầu cấp nước cho năm tiếp theo.

Trước những khó khăn và tồn tại nêu trên, Bộ Công Thương đã đề nghị sửa đổi nội dung về quản lý đập, hồ chứa thuỷ điện trong Luật Điện lực để thống nhất trong quản lý. Các bộ ngành từ đó thống nhất, xây dựng cơ chế phối hợp điều tiết nước các hồ chứa trong mùa kiệt, rà soát các quy định về điều tiết nước các hồ chứa thủy điện, thủy lợi để cấp nước cho hạ du trong thời kỳ mùa kiệt và đảm bảo cấp nước cho các hệ thống thủy lợi trong mùa kiệt. Bên cạnh đó, nghiên cứu điều chỉnh linh hoạt thời gian tích nước của các thủy điện trong quy trình liên hồ, tăng cường độ chính xác của công tác dự báo thủy văn, nghiên cứu hiệu chỉnh các quy định linh hoạt để thích nghi với biến đổi khí hậu và các điều kiện thủy văn diễn biến khó 
lường, vừa đảm bảo an toàn hồ chứa vừa đảm bảo khả năng tích nước phục vụ sản xuất điện và nhu cầu nước hạ du [6].

Việc quản lý an toàn đập, hồ chứa thủy điện hiện được điều chỉnh bởi nhiều văn bản quy phạm pháp luật, như: xây dựng; khí tượng, thủy văn; phòng chống thiên tai; quản lý an toàn đập, hồ chứa nước... dẫn đến những vướng mắc trong quá trình thực hiện. Bên cạnh đó, các quy định của pháp luật hiện còn một số bất cập, chồng chéo. Điển hình như quy định về cắm mốc khu vực lòng hồ được quy định đồng thời tại Nghị định số 114/2018/NĐ-CP [15], Nghị định số 112/2008/NĐ-CP [21], Nghị định số 43/2015/NĐ-CP [22] của Chính phủ và Thông tư số 03/2012/TT-BTNMT của Bộ Tài nguyên và Môi trường [24]. Nếu tuân thủ tất cả các quy định này thì khu vực lòng hồ phải cắm quá nhiều mốc, các đường biên cắm mốc nhiều trường hợp trùng nhau (cùng lấy theo cao trình đỉnh đập) hoặc khá gần nhau (theo cao trình đỉnh đập và theo cao trình mực nước lũ kiểm tra có tính đến nước dềnh).

Không chỉ có vậy, một số quy định không rõ ràng nên khó triển khai thực hiện như trường hợp Nghị định 114/2018/NĐ-CP [15] quy định vùng hạ du đập là vùng bị ngập lụt khi hồ xả nước theo quy trình; xả lũ trong tình huống khẩn cấp hoặc vỡ đập nhưng lại không quy định trường hợp nào thì xác định theo quy trình, theo tình huống khẩn cấp hoặc vỡ đập. Quy định này cũng khó xác định được vùng hạ du trong trường hợp các hồ chứa được xây dựng bậc thang hoặc hồ chứa được xây dựng ở gần nơi hợp lưu với sông khác.

Ngoài ra, trong quá trình thực thi nhiệm vụ, các cơ quan chức năng cũng gặp phải những khó khăn do thiếu nhân lực, nhất là nhân lực có chuyên môn về thủy công hoặc liên quan đến thủy điện từ cấp trung ương đến địa phương. Trong khi đó, công tác phối hợp giữa các cơ quan chức năng có lúc, có nơi chưa hiệu quả từ khâu xây dựng văn bản quy phạm pháp luật đến tổ chức thực hiện và kiểm tra, giám sát.

Nghị định 114/2018/NĐ-CP [15] về quản lý an toàn đập hồ chứa đã quy định về quản lý an toàn đập, hồ chứa nước đối với đập có chiều cao từ $5 \mathrm{~m}$ trở lên hoặc hồ chứa nước có dung tích toàn bộ từ $50.000 \mathrm{~m}^{3}$ trở lên và an toàn cho vùng hạ du đập. Công tác quản lý an toàn đập, hồ chứa nước phải được thực hiện thường xuyên, liên tục trong suốt quá trình khảo sát, thiết kế, thi công xây dựng, quản lý, khai thác và bảo vệ đập, hồ chứa nước. Chủ sở hữu đập, hồ chứa nước chịu trách nhiệm về an toàn đập, hồ chứa nước do mình sở hữu; tổ chức, cá nhân khai thác đập, hồ chứa nước có trách nhiệm quản lý, khai thác, bảo đảm an toàn, phát huy hiệu quả của công trình. Tuy nhiên, Nghị định này vẫn chưa có quy định cụ thể về phân loại quy trình điều tiết cho từng cấp hồ, đập (hồ đập chứa nước quan trọng đặc biệt, hồ đập chứa nước lớn, hồ đập chứa nước vừa, hồ đập nhỏ) và bản đồ sơ tán dân trong tình huống khẩn cấp xả lũ, vỡ đập. Do đó nên ban hành thông tư hướng dẫn chi tiết các điều trong nghị định này.

Nghị định 143/2003/NĐ [25] Qui định chi tiết một số điều cụ thể của Pháp lệnh khai thác và bảo vệ Công trình thuỷ lợi nhưng chưa cụ thể hoá được những điều khoản liên quan đến an toàn đập. Tuy vậy, Nghị định này cũng đã tạo được khung pháp lý cho việc thực hiện một số nội dung liên quan đển an toàn đập như phể duyệt, thẩm định dự án nâng cấp sửa chữa công trình, nguồn tài chính, phạm vi bảo vệ công trình thuỷ lợi, trong đó có đập (Điều 25-28), đặc biệt là đã qui định nội dung chức năng quản lý nhà nước về khai thác và bảo vệ công trình thuỷ lợi (Điều 29), đã gắn khai thác công trình với bảo vệ an toàn, đặc biệt là gắn trách nhiệm của người hưởng lợi từ công trình thuỷ lợi tham gia phương án bảo vệ, xử lý sự cố (Điều 22 , 23).

Ủy ban nhân dân (UBND) cấp tỉnh đã cụ thể hoá các chủ trương, tổ chức triển khai thực hiện các qui định về an toàn đập, xây dựng các phương án về an toàn đập nhất là về mùa lũ và chỉ đạo các ngành, chính quyến các cấp trong tỉnh thực hiện các nhiệm vụ về an toàn đập đã được giao. Sở NN\&PTNT là cơ quan thường trực tham mưu cho UBND tỉnh ban hành các cơ chế chính sách, chỉ đạo phòng chống lũ lụt, an toàn đập trên địa bàn tỉnh, thực hiện phương châm "4 tại chỗ" gồm chỉ huy tại chỗ; lực lượng tại chỗ; phương tiện, vật tư tại chỗ và hậu cầu tại chỗ; đảm bảo 3 giai đoạn trước, trong và sau thiên tai; phù hợp với tình hình thực tế tại địa phương [26]. 


\subsection{Khung pháp lý quản lý tổng hợp an toàn hồ đập tại Việt Nam}

Phân tích đánh giá tổng quan một số mô hình quản lý tổng hợp lũ lụt và an toàn hồ đập của các nước phát triển trên thế giới, vấn đề thể chế chính sách quản lý tổng hợp lũ lụt và an toàn đập ở Việt Nam, xuất phát từ nhu cầu thực tiễn trong công tác quản lý an toàn đập trong thời gian vừa qua tại các tỉnh trong khu vực nghiên cứu, đồng thời căn cứ theo điều kiện tự nhiên và kinh tế xã hội của các địa phương, tác giả đã đề xuất khung pháp lý quản lý an toàn hồ đập tại Việt Nam được mô tả trên Hình 1.

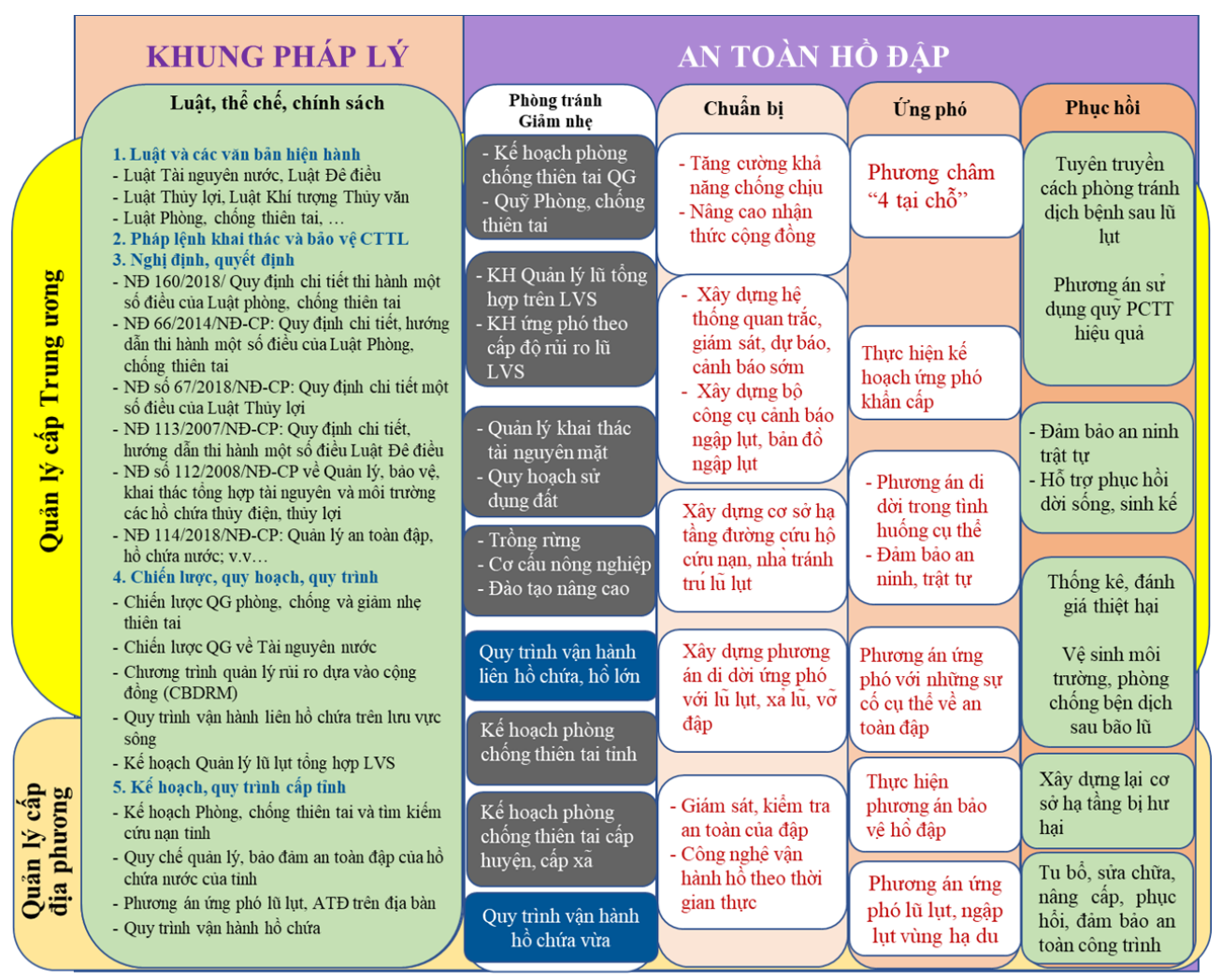

Hình 1. Sơ đồ khung pháp lý quản lý tổng hợp an toàn hồ đập tại Việt Nam.

Để thực hiện được quản lý tổng hợp an toàn hồ đập tại Việt Nam, cần tiến hành các hoạt động về tăng cường thể chế chính sách pháp luật về quản lý an toàn đập và hàng loạt các hành động "Phòng tránh, giảm nhẹ", "Chuẩn bị", "Ứng phó” và "Phục hồi” ở cả cấp Trung ương và địa phương (Hình 1 ) nhằm phòng tránh các tác động về rủi ro an toàn hồ đập, xây dựng và thực hiện tốt các kế hoạch để chuẩn bị, ứng phó với các tình huống rủi ro thiên tai và an toàn hồ đập, và các kế hoạch phục hồi giảm thiểu thiệt hại về người và tài sản [26-27].

Mục tiêu của công tác "Chuẩn bị” là tăng cường năng lực của các cấp chính quyền địa phương, cơ quan chuyên môn, doanh nghiệp và khả năng chống chịu của cộng đồng trước trong và sau lũ do xả lũ khẩn cấp từ hồ chứa và vỡ đập. Trong công tác "Chuẩn bị” có một số hoạt động như: (i) Nâng cao nhận thức của của cộng đồng về rủi ro ngập lụt và thiệt hại do xả lũ khẩn cấp từ hồ chứa và vỡ đập; (ii) Giám sát, kiểm tra an toàn hồ đập, các bộ phận của công trình đầu mối; (iii) Xây dựng, mở rộng hệ thống quan trắc, giám sát, dự báo và cảnh báo sớm các rủi ro thiên tai do lũ, an toàn công trình hồ chứa, đập dâng trên các lưu vực sông. Ưu tiên giải pháp công nghệ hỗ trợ vận hành hệ thống hồ chứa, đập dâng theo thời gian thực; (iv) Xây dựng bộ công cụ cảnh báo ngập lụt và bản đồ ngập lụt; (v) Xây dựng cơ sở hạ tầng, bao gồm đường giao thông cứu hộ cứu nạn, nhà cộng đồng phòng chống thiên tai, bản đồ sơ tán dân; (vi) Xây dựng kế hoạch chuẩn bị, ứng phó sự cố công trình hồ chứa và ngập lụt vùng hạ lưu do xả lũ vỡ đập; (vii) Xây dựng phương án chuẩn bị, ứng phó, di dời trong các tình huống khẩn cấp; và (viii) Rà soát, diễn tập theo các kịch bản, phương án ứng phó đã xây dựng. 
Các hoạt động trong nội dung "Ứng phó" bao gồm việc rà soát, cập nhật, bổ sung phương châm "4 tại chỗ" trong công tác chỉ huy, điều hành ứng phó đảm bảo an toàn công trình và ngập lụt vùng hạ lưu do xả lũ vỡ đập; Chủ động, thực hiện được các phương án ứng phó cụ thể tương ứng với các kịch bản xảy ra trong điều kiện thực tế. Đối với nội dung "Phục hồi”, cần đạt được các mục tiêu là đánh giá được các thiệt hại vùng hạ lưu sau sự cố thiên tai, xả lũ, vỡ đập, nhanh chóng khắc phục các hậu quả để giảm thiểu đến mức tối đa các tổn thất có thể tiếp tục xảy ra do sự cố này và phục hồi sinh kế của người dân [26-27].

\section{Kết luận}

Bài báo này đã phân tích một số mô hình quản lý tổng hợp lũ lụt và an toàn hồ đập của các nước phát triển trên thế giới, vấn đề thể chế chính sách quản lý tổng hợp lũ lụt và an toàn đập ở Việt Nam. Kết quả cho thấy vấn đề quản lý an toàn đập đã được các nước, đặc biệt Chính phủ và các Bộ ngành từ Trung ương đến địa phương quan tâm. Chính phủ và các bộ ngành đã ban hành nhiều văn bản quy định việc quản lý an toàn đập và được hoàn thiện dần cho đến hiện tại, tuy nhiên vẫn còn có một số tồn tại trong thể chế quản lý an toàn hồ đập. Từ đó, các tác giả đã đề xuất khung pháp lý quản lý an toàn hồ đập tại Việt Nam, bao gồm các hoạt động về tăng cường thể chế chính sách pháp luật về quản lý an toàn đập và hàng loạt các hành động nhằm phòng tránh các tác động về rủi ro an toàn hồ đập, xây dựng và thực hiện tốt các kế hoạch để chuẩn bị, ứng phó với các tình huống rủi ro thiên tai và an toàn hồ đập, và các kế hoạch phục hồi giảm thiểu.

Đóng góp của tác giả: Xây dựng ý tưởng nghiên cứu: N.C.Đ., N.T.M.H; Lựa chọn phương pháp nghiên cứu: N.T.M.H; Phân tích kết quả: N.T.M.H.; Viết bản thảo bài báo: N.C.Đ, N.T.M.H; Chỉnh sửa bài báo: N.C.Đ., N.T.M.H., N.A.Đ.

Lời cảm ơn: Một phần kết quả trình bày trong Bài báo này sử dụng một số tư liệu của đề tài "Nghiên cứu co' sở khoa hoc phuc vu công tác cảnh báo ngập lụt hạ lưu hồ chứa nước và đề xuất giải pháp úng phó cho các hồ, đập và vùng hạ du trong các tình huống xã lũ võ đập khu vục Bắc Trung Bộ (BTB)", mã số KC.08.33/16-20 thuộc Chương trình "Nghiên cứu khoa học và công nghệ phục vụ bảo vệ môi trường và phòng tránh thiên tai”, Mã số KC08/16-20 của Bộ Khoa học và Công nghệ.

Lời cam đoan: Tập thể tác giả cam đoan bài báo này là công trình nghiên cứu của tập thể tác giả, chưa được công bố ở đâu, không sao chép từ những nghiên cứu trước đây; không có sự tranh chấp lợi ích trong nhóm tác giả.

\section{Tài liệu tham khảo}

1. Đơn, N.C. Báo cáo nghiên cứu khả thi dự án Quản lý thiên tai Việt Nam (VNHaz/WB5), 2012, 165 trang.

2. Bộ Tài nguyên và Môi trường. Kịch bản Biến đổi khí hậu và Nước biển dâng cho Việt Nam, 2009.

3. Bộ Tài nguyên và Môi trường. Kịch bản Biến đổi khí hậu và Nước biển dâng cho Việt Nam, 2012.

4. Thục, T.; Thắng, N.V.; Hương, H.T.L.; Khiêm, M.V.; Hiển, N.X.; Phong, D.H. Kịch bản Biến đổi khí hậu và Nước biển dâng cho Việt Nam. Bộ Tài nguyên và Môi trường công bố, 2016.

5. Đơn, N.C. Bối cảnh và sự cần thiết của Dự án "Sửa chữa và Nâng cao an toàn đập". Báo cáo nghiên cứu khả thi Dự án WB8, do Viện KHTLVN lập, 2015, 323 trang.

6. Văn phòng Quốc hội. Công tác quản lý an toàn đập, hồ chứa thủy điện hiện nay. Tin hoạt động Quốc hội, 2020. Trang online: http://quochoi.vn/tintuc/Pages/tin-hoatdong-cua-quoc-hoi.aspx?ItemID=47661, truy cập 20 tháng 8 năm 2020. 
7. Quý, P.N. Báo cáo tổng hợp đề tài cấp Bộ "Nghiên cứu tác động của biến đổi khí hậu đến sự an toàn đập đất của hồ chứa nước và đề xuất bộ tiêu chí đánh giá an toàn đập giai đoạn 2013-2015", 2015.

8. Bộ Đất đai, Cơ sở hạ tầng, Giao thông và Du lịch, Nhật Bản, (MLIT). Trang online: https://www.mlit.go.jp/, truy cập 20 tháng 8 năm 2020 .

9. MOIS (Bộ Nội vụ và An ninh Hàn quốc 행정자치부, Haengjeong-Jachi-Bu). Trang online: https://www.mois.go.kr/, truy cập 20 tháng 8 năm 2020.

10. Luật Tài nguyên nước 08/1998/QH10. Trang online: http://vbpl.vn/TW/Pages/vbpq-luocdo.aspx?ItemID=7752, truy cập 20 tháng 8 năm 2020.

11. Luật Phòng, Chống thiên tai, 33/2013/QH13. Trang online: http://vbpl.vn/boquocphong/Pages/vbpq-luocdo.aspx?ItemID=32516, truy cập 20 tháng 8 năm 2020 .

12. Luật Thủy lợi, 08/2017/QH14. Trang online: http://vbpl.vn/bonongnghiep/Pages/vbpq-van-ban-goc.aspx?ItemID=126723, truy cập 20 tháng 8 năm 2020 .

13. Luật Đê điều 79/2006/QH11. Trang online: http://vbpl.vn/TW/Pages/vbpq-luocdo.aspx?ItemID=14831, truy cập 20 tháng 8 năm 2020.

14. Luật 60/2020/QH14 Sửa đổi, bổ sung một số điều của Luật phòng, chống thiên tai và Luật đê điều có hiệu lực thi hành từ ngày 01 tháng 7 năm 2021. Trang online: http://vbpl.vn/TW/Pages/vbpq-van-ban-goc.aspx?ItemID=142846, truy cập 20 tháng 8 năm 2020.

15. Nghị định 114/2018/NĐ-CP: Quản lý an toàn đập, hồ chứa nước. Trang online: http://vbpl.vn/bonongnghiep/Pages/vbpq-van-ban-goc.aspx?ItemID=132219, truy cập 20 tháng 8 năm 2020 .

16. Nghị định số 67/2018/NĐ-CP: Quy định chi tiết một số điều của Luật Thủy lợi. Trang online: http://vanban.chinhphu.vn/portal/page/portal/chinhphu/hethongvanban?class_id=1 \&_page=1\&mode=detail\&document_id=193712, truy cập 20 tháng 8 năm 2020.

17. Nghị định 160/2018/NĐ-CP: Quy định chi tiết thi hành một số điều của Luật phòng, chống thiên tai. Trang online: http://vbpl.vn/TW/Pages/vbpq-luocdo.aspx?ItemID=132307, truy cập 20 tháng 8 năm 2020.

18. Thông tư 33/2008/TT-BNN ngày 04/02/2008 của Bộ NNPTNT: Hướng dẫn thực hiện một số điều thuộc Nghị định số $72 / 2007 / \mathrm{NĐ-CP}$ về quản lý an toàn đập. Trang online:

https://thuvienphapluat.vn/van-ban/tai-nguyen-moi-truong/Thong-tu-33-2008-TT-B NN-quan-ly-an-toan-dap-huong-dan-Nghi-dinh-72-2007-ND-CP-62574.aspx, truy cập 20 tháng 8 năm 2020 .

19. Thông tư số 34/2010/TT-BTC ngày 07/10/2010 của Bộ Công thương: Quy định về quản lý an toàn đập của công trình thủy điện. Trang online: http://vbpl.vn/TW/Pages/vbpq-van-ban-goc.aspx?ItemID=25744

20. Nghị định 21/2013/NĐ-CP: Quy định chức năng, nhiệm vụ, quyền hạn và cơ cấu tổ $\begin{array}{llll}\text { chức của } & \text { Bộ } & \text { TNMT. } & \text { Trang } \\ \text { online: }\end{array}$ https://thuvienphapluat.vn/van-ban/bo-may-hanh-chinh/Nghi-dinh-21-2013-ND-CP -chuc-nang-nhiem-vu-quyen-han-co-cau-Bo-Tai-nguyen-174900.aspx, truy cập 24 tháng 8 năm 2020.

21. Nghị định số $112 / 2008 / \mathrm{NĐ-CP}$ về Quản lý, bảo vệ, khai thác tổng hợp tài nguyên và môi trường các hồ chứa thủy điện, thủy lợi. Trang online: 
http://vanban.chinhphu.vn/portal/page/portal/chinhphu/hethongvanban?class_id=1 \&mode=detail\&document_id=79588, truy cập 24 tháng 8 năm 2020.

22. Nghị định 43/2015/NĐ-CP về Quy định lập, quản lý hành lang bảo vệ nguồn nước. Trang online: http://dwrm.gov.vn/index.php?language=vi\&nv=laws\&op=Tai-nguyen-nuoc/Nghidinh-so-43-2015-ND-CP-cua-Chinh-phu-Quy-dinh-lap-quan-ly-hanh-lang-bao-venguon-nuoc, truy cập 24 tháng 8 năm 2020.

23. Nghị định 201/2013/NĐ-CP Quy định chi tiết thi hành một số điều của Luật Tài nguyên nước. Trang online: http://vbpl.vn/botainguyen/Pages/vbpq-van-ban-goc.aspx?ItemID=32649, truy cập 24 tháng 8 năm 2020.

24. Thông tư 03/2012/TT-BTNMT ngày 12 tháng 4 năm 2012 của Bộ TNMT Quy định việc quản lý, sử dụng đất vùng bán ngập lòng hồ thủy điện, thủy lợi. Trang online: https://luatvietnam.vn/dat-dai/thong-tu-03-2012-tt-btnmt-bo-tai-nguyen-va-moi-tru ong-69661-d1.html, truy cập 24 tháng 8 năm 2020.

25. Nghị định 113/2007/NĐ-CP: Quy định chi tiết, hướng dẫn thi hành một số điều của Luật Đê điều. Trang online: http://vanban.chinhphu.vn/portal/page/portal/chinhphu/hethongvanban?class_id=1 \&mode=detail\&document_id=29321, truy cập 24 tháng 8 năm 2020.

26. Giáp, N.Đ. Báo cáo Đề tài cấp Bộ "Nghiên cứu xây dựng khung quản lý tổng hợp lũ một số lưu vực sông điển hình ven biển miền Trung”, 2018, 250 trang.

27. Đơn, N.C. Báo cáo Nội dung 3 “Quy trình và khung pháp lý phục vụ cảnh báo ngập lụt cho vùng hạ du các hồ, đập khu vực Bắc Trung Bộ” Đề tài KC.08.33/16-20.

\title{
A newly integrated legal framework for dam safety management in Vietnam
}

\author{
Nguyen Cao Don ${ }^{1}$, Nguyen Thi Minh Hang ${ }^{2 *}$, Nguyen Anh Duc ${ }^{3}$ \\ ${ }^{1}$ Department of Water resource Planning and Forecasting, Water Research Institute \\ (Ministry of Natural Resources and Environment); No. 8 Phao Dai Lang Str., Dong Da, \\ Hanoi, Vietnam; ncaodonwri@gmail.com \\ 2 Thuyloi University, No. 175 Tay Son Str., Dong Da Dist., Hanoi, Vietnam; \\ hangntm@tlu.edu.vn \\ 3 Water Research Institute (Ministry of Natural Resources and Environment), No. 8 Phao \\ Dai Lang Str., Dong Da, Hanoi, Vietnam; nganhduc@yahoo.com
}

\begin{abstract}
This paper analyzes management models of integrated flood and dam safety in developed countries and Vietnam in term of institutional and policy issues for integrated flood management and reservoir dam safety. The results show that dam safety management has been much concerned by the governments and ministries from central to local levels. The governments and line ministries have issued many laws, decrees and circulars and so on for controlling dam safety issues, which have been gradually improved up to now, however there are still some shortcomings in dam safety management institutions. Since then, the authors have proposed a legal framework for dam safety management in Vietnam, including activities to strengthen the legal and policy institutions on dam safety management and a series of actions in order to cope with dam safety risks, develop strategy in disaster risk management and emergency preparedness systems, implement action plans for national and regional resilience.
\end{abstract}

Keywords: Legal framework; Dam safety; Emergent action plan; Reservoir and dam; Safety risk management. 